\title{
Properties of Adult Lung Stem and Progenitor Cells
}

\author{
Ivan Bertoncello
}

Lung Health Research Centre, Department of Pharmacology and Therapeutics, University of Melbourne, Victoria 3010, Australia

\section{Address for Correspondence:}

Ivan Bertoncello PhD

Lung Health Research Centre

Department of Pharmacology and Therapeutics

University of Melbourne

Victoria 3010, Australia

Email: IvanB@unimelb.edu.au

Running Head: Lung epithelial stem and progenitor cells

Keywords: lung epithelial stem cells; lung regeneration and repair; cell differentiation; clonogenic assay; mouse models

This manuscript contains: 2 Figures and 1 Table.

ABSTRACT

The last decade has seen significant progress in understanding the organisation of regenerative cells in the adult lung. Cell lineage tracing and in vitro clonogenic assays have enabled the identification and characterisation of endogenous lung epithelial stem and progenitor cells. Selective lung injury models, and genetically engineered mice have revealed highly conserved gene networks, factors, signalling pathways, and cellular interactions important in maintaining lung homeostasis and regulating lung regeneration and repair following injury. This review 
describes the current models of lung epithelial stem and progenitor cell organisation in adult mice, and the impediments encountered in translational studies aiming to identify and characterise their human homologs.

\section{Introduction}

The respiratory system arises from an outpouching of the anterior foregut of the developing embryo by undergoing branching morphogenesis to progressively form the arborizing proximal and distal airways and alveolar bed of the adult lung (Morrisey and Hogan, 2010). This process involves the precisely orchestrated crosstalk between primitive lung endodermal and mesodermal cell lineages, and the coordinated activity of critical gene networks and molecular pathways, to generate a highly vascularised respiratory tree comprising some 40 to 60 functionally differentiated cell lineages essential for maintaining organ integrity, airway patency, mucocilliary clearance, and gas exchange. Postnatally, lung growth and maturation continues until body growth stops; and lung size and body mass are linearly correlated (Burri, 2006).

The adult lung was long thought a conditionally renewing organ with limited regenerative potential (Goss, 1966). This perception was primarily based on the very slow turnover rate ( 1\% per day) of airway and alveolar epithelia (Bowden, 1983) compared to archetypal continuously renewing organs (Bertoncello and McQualter, 2013). Consequently, recovery of lung function following partial pneumonectomy was initially thought to predominantly involve remodelling and compensatory hypertrophy of existing structural and functional units rather than de novo regeneration of airway or alveolar tissue. However, we now understand that slow cell turnover reflects the long lifespan and slow rate of attrition of lung epithelial cells in the unperturbed lung (Rawlins and Hogan, 2008), while factors including fibrotic scarring, and progressive stiffening and loss of elastic recoil of the extracellular matrix (ECM) scaffold in the ageing lung impair the ability of progenitor cells to remediate injury (White, 2015).

Early autoradiographic studies in rodent models exposed to toxicants revealed differing rates of cell turnover along the proximal-distal axis of the lung (Shorter et al., 1964), and identified airway basal cells (Hackett, 1979), non-ciliated club cells in the terminal bronchioles (Evans et al., 1976), and Type 2 epithelial (AT2) cells in the alveolar bed (Adamson and Bowden, 1974) as presumptive progenitor cells. In ensuing years, the 
analysis of adult lung progenitor cells has employed increasingly powerful experimental designs to establish the identity, spatial location and regenerative potential of adult lung progenitor cells. The development of robust cell lineage-tracing and fate-mapping protocols and genetically engineered mouse models, and technological advances in cell separation, analytical cytology, and cell culture systems underpins the current understanding of their role in lung regeneration and repair and the factors that specify their fate.

Experimentation in inbred mouse strains and models housed in highly controlled specific pathogen-free environments have been the mainstay of this work. This work shows (1) that both multipotent and region-specific lineage restricted progenitor cells maintain and repair proximal and distal airway and alveolar epithelial cell lineages; (2) that different progenitor cell subpopulations are recruited to repair injury of different type and severity; (3) that their regenerative potential is context dependent and dictated by instructive cues provided by their niche microenvironment; and (4) that repair invokes the same critical factors, genes and pathways that build the lung during development.

\section{Organisation of epithelial cell lineages in the adult mouse lung}

The respiratory tree of the adult mouse lung comprises approximately 13 generations of highly vascularised branching and tapering conducting airways which transmit air to, and from, the gas-exchanging epithelium of the alveolar bed. Histomorphometric analysis reveals significant regional differences in the composition and functional specialisation of respiratory epithelial cell lineages along the proximal-distal axis (Kotton and Morrisey, 2014; Rock et al., 2009; Williams and Roman, 2016).

The trachea and mainstem bronchiolar airways of mice are lined by a pseudostratified epithelium comprising basal cells, secretory cells and ciliated cells while submucosal glands (SMG) which produce the majority of serous and mucous secretions in the airway are restricted to the subepithelial layer of the upper trachea. This pseudostratified epithelium transitions into a simple cuboidal epithelium in the proximal bronchiolar airways devoid of basal cells and predominantly comprising secretory club cells and ciliated cells. 
Rare innervated pulmonary neuroendocrine cells (PNEC) are dispersed throughout the proximal and distal bronchiolar airways, and neuroepithelial bodies (NEB) are located at airway branch-points and at the bronchiolar duct junction (BADJ) of terminal bronchioles that give rise to alveolar ducts and alveoli lined with cuboidal surfactant-secreting AT2 cells and squamous gas-exchanging AT1 (Cutz, 2015).

\section{Adult mouse lung stem and progenitor cells}

The epithelial cell lineages lining each of the anatomical compartments of the airway are maintained by diverse pools of regional stem and progenitor cells distributed along the proximal-distal lung axis and the alveolar bed (Figure 1).

Progenitor cells of the tracheal and proximal airways: Cell lineage tracing in lung injury models, flow cytometric analysis (FACS) and in vitro proliferation and differentiation assays have identified basal cells located in the ducts of SMG, and in the pseudostratified epithelium as the multipotent stem cells which maintain the integrity of the respiratory epithelium of the tracheal and proximal bronchiolar airways (Hegab et al., 2015). These self-renewing basal cells generate the mucus and serous secreting cells of SMG as well as ciliated cells, PNEC, and the secretory goblet and club cell lineages of the proximal airways (Borthwick et al., 2001; Ghosh et al., 2011; Hegab et al., 2011; Hong et al., 2004a). Secretoglobin family $1 \mathrm{~A}$, member 1 positive $\left(\mathrm{Scgb} 1 \mathrm{a} 1^{\text {pos}}\right)$ club cells also function as a transit amplifying progenitor cell pool able to replace senescent club cells in the steady state. Following severe injury tracheal Scgb1a $1^{\text {pos }}$ club cells display an enhanced but limited ability to self-renew, de-differentiate and contribute to the regeneration of basal cells and ciliated cells (Rawlins et al., 2009).

Different basal cell subpopulations in the upper airways are characterised and resolved on the basis of their differential and variable expression of cell surface markers including transformation related protein 63 (p63); the keratins 5, 8, and 14 (Krt5, Krt8 and Krt14); the nerve growth factor receptor (NGRF); the epithelial cell surface glycoprotein (Trop2); and the integrin alpha chain 6 ( $\alpha 6$ ). The signature profile of basal cells depends on their spatial location in the trachea and proximal airways, and their involvement in tracheal and proximal airway epithelial regeneration and repair (Cole et al., 2010; Ghosh et al., 2011; Hegab et al., 2015; Hong et al., 2004b; Rock et al., 2009; Rock et al., 2010). While 
some changes are due to up- or down-regulation of specific markers as normally quiescent cells are activated and recruited into cycle, cell lineage tracing has also revealed significant heterogeneity in the regenerative potential of basal cell clones with differing signature profiles. In the trachea, a discrete Trop2 ${ }^{\text {pos }} \alpha 6^{\text {pos }}$ SMG ductal basal cell type able to regenerate SMG ducts, tubules and secretory and ciliated airway cells has also been identified (Hegab et al., 2011). In the proximal airways, the majority of basal cells are $\mathrm{p}^{\mathrm{pos}}{ }^{\mathrm{pos}} \mathrm{Krt} 5^{\mathrm{pos}} \mathrm{Krt} 14^{\text {neg }}$, and less than $20 \%$ are $\mathrm{Krt} 5^{\text {pos }} \mathrm{Krt1} 4^{\text {pos }}$. The significant expansion of $\mathrm{Krt} 5^{\text {pos }} \mathrm{Krt} 14^{\text {pos }}$ basal cells following injury has been interpreted as marking the activation and recruitment of unipotent self-renewing $\mathrm{Krt} 5^{\mathrm{pos}} \mathrm{Krt} 14^{\text {pos }}$ basal progenitor cells able proliferate and regenerate both club and ciliated cells. (Ghosh et al., 2011). However, recent studies have led to revision and refinement of this model.

Cell lineage tracing and analysis of the clonal dynamics of basal cell proliferation in the proximal airways has revealed that $\mathrm{p} 63^{\text {pos }} \mathrm{Krt5} 5^{\text {pos }}$ basal stem cells give rise to $\mathrm{Krt}^{\text {pos }}$ progenitor cells with basal cell morphology that in turn generates bipotent short-lived luminal secretory cells that are precursors of the secretory and ciliated cell lineages of the proximal airways (Watson et al., 2015). Following injury, the proliferation, fate

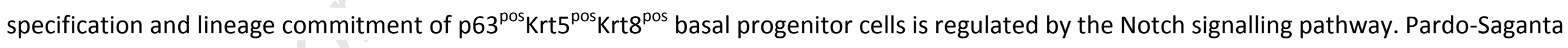
et al (2015) further refined this model on the basis of cell lineage tracing following $\mathrm{SO}_{2}$ ablation of tracheobronchial luminal epithelial cells. This study showed that $\mathrm{p} 63^{\text {pos }} \mathrm{Krt5}{ }^{\text {pos }}$ basal cells segregate into two subpopulations following injury: the basal cell precursor of secretory cells coexpressing the activated intracellular Notch2 domain ( $\mathrm{N} 2 \mathrm{ICD}^{\text {pos }}$ ); and the basal cell precursor of ciliated cells co-expressing c-myb ${ }^{\text {pos }}$ (Figure $\mathbf{2 A}$ ). These basal cell subpopulations subsequently express Krt8 and progressively lose basal cell markers as they differentiate (Pardo-Saganta et al., 2015). Yet another study showed that fully differentiated secretory cells were able to dedifferentiate and replenish the basal stem cell compartment after ablation of endogenous basal cells in a doxycycline regulated conditional Krt5 genetically engineered mouse model (Tata et al., 2013).

These studies reveal significant heterogeneity and plasticity in the stem and progenitor cell compartments of the proximal airways. While notch signalling plays a key role in regulating basal cell lineage commitment and differentiation in the proximal airways (Carraro and Stripp, 2015; 
Hogan et al., 2014), there is still much to learn about homeostatic mechanisms which determine fate choices of proximal airway stem and progenitor cells in the steady state and following injury.

Progenitor cells of the distal airways: The cuboidal respiratory epithelium of the distal conducting airways are populated by Scb1a $1^{\text {pos }}$ club cell derived secretory cells, ciliated cells. Rare PNEC comprising less than $1 \%$ of the airway epithelium also form innervated NEB that function as hypoxia-, chemo- and mechanotransduction-sensory cells, and regulate immune responses by elaboration of neuropeptides (Branchfield et al., 2016; Cutz, 2015). Unlike the trachea and proximal airways, the distal airways of the mouse are devoid of basal cells (Rock et al., 2009).

In the steady state or following mild perturbation, Scb1a1 $1^{\text {pos }}$ club cells of the distal lung function as a large reservoir of transit amplifying progenitor cells in the distal bronchiolar airways (Evans et al., 1978). By exploiting the selective toxicity of naphthalene to ablate club cells that express cytochrome P450 isozyme 2 F2 (CYP2F2), naphthalene-resistant (CYP2F2 ${ }^{\text {neg }}$ ) Scgb1a $1^{\text {pos }}$ variant club cells intimately juxtaposed to NEB at airway branch-points have been identified as critical multipotent self-renewing stem cells essential for bronchiolar epithelial regeneration following severe injury (Giangreco et al., 2009; Hong et al., 2001). Separate, distinct surfactant protein C positive (SPC ${ }^{\text {pos }}$ ) bronchioalveolar stem cells (BASC) located at the BADJ in terminal bronchioles are also activated in response to injury to replace both bronchiolar and alveolar epithelial cells (Kim et al., 2005; Nolen-Walston et al., 2008; Tropea et al., 2012).

Analysis of the clonal dynamics of organoid formation in 3-dimensional culture systems has also been used to more precisely classify and hierarchically order lung epithelial stem and progenitor cells on the basis of their ability to self-renew and give rise to descendent lineages. When grown at an air-liquid interface embedded in hydrogels such as matrigel, epithelial stem/progenitor cells proliferate to form 3dimensional multicellular spheroidal and branching organoids that recapitulate the apical-basal organisation, differentiation and functionality of epithelia in the respiratory compartments from which they are derived (Nadkarni et al., 2015).

Using this approach in combination with flow cytometry we identified a multipotent, EpCAM ${ }^{\text {hi }} \alpha 6^{\text {pos }} \beta 4^{\text {pos }} S c a-1^{\text {lo }} C D 24^{\text {lo }}$ self-renewing epithelial stem/progenitor cell (EpiSPC) in the distal lung (McQualter et al., 2010). When co-cultured in matrigel with lung mesenchymal stromal cells (MSC), EpiSPC gave rise to mixed colonies comprising multipotent self-renewing cells and differentiated airway and alveolar epithelial cells, and 
lineage-restricted colonies with more limited proliferative potential comprising either airway, or alveolar epithelial cells. Other studies subsequently showed that BASC shared an EpCAM ${ }^{\mathrm{hi}} \mathrm{Sca}-1^{\mathrm{lo}} \mathrm{CD} 24^{\mathrm{lo}}$ signature profile (Zacharek et al., 2011); and also demonstrated the existence of multipotent Scb1a1 ${ }^{\text {neg }} S P C^{\text {neg }} \alpha 6^{\text {pos }} \beta 4^{\text {pos }}$ epithelial progenitor cells in the distal lung (Chapman et al., 2011). Subsequent analysis of the spatial distribution of EpCAM ${ }^{\text {hi }} \mathrm{CD} 24^{\text {lo }}$ stem/progenitor cells in Rosa26R-Confetti mice and SFTPC-GFP reporter mice, showed that progenitors generating mixed colonies similar to those described by McQualter et al., (2010) were restricted to the bronchiolar airways; whereas airway lineage-, and alveolar lineage-restricted progenitors were located predominantly in the intra-pulmonary conducting airways and the alveolar bed respectively (Chen et al., 2012).

Because different FACS gating strategies, proliferation assays and models have been used to characterise theses multipotent progenitor cell cohorts expressing overlapping markers, their precise relationship remains to be determined. However, these studies are consistent with a hierarchically ordered model of epithelial stem and progenitor cell organisation where the day-to-day replacement of senescent differentiated cells is met by cell lineage-restricted progenitor cells, and long-lived multipotent self-renewing stem cells are recruited to regenerate descendent lineages following severe injury (Giangreco et al., 2009)

On the other hand, PNEC are a unipotent cell lineage which relies on cell turnover as the only mechanism of their renewal. PNEC originate in the foregut endoderm, and are the first epithelial cell type to differentiate in the primitive airways (Cutz, 2015). During development PNEC detach from the airway epithelium and migrate to cluster at airway branch-points by a process termed "slithering" (Kuo and Krasnow, 2015), to form innervated NEB that function as hypoxia-, chemo- and mechanotransduction-sensory cells in the adult lung, and regulate immune responses by elaboration of neuropeptides (Branchfield et al., 2016; Cutz, 2015). PNEC and NEB are quiescent populations in the uninjured lung but proliferate rapidly during recovery from injury by hyperplastic growth (Peake et al., 2000; Reynolds et al., 2000). Once permanently ablated this lineage does not recover (Song et al., 2012).

Progenitor cells of the alveolar bed: Self-renewing AT2 cells are the stem cells responsible for the homeostatic maintenance of the alveolar epithelium (Barkauskas et al., 2013). However, recent lineage tracing studies utilising injury modalities of varying severity have shown that 
alternative progenitor cell pools can be recruited to regenerate and repair the alveolar epithelium following severe injury (Jain et al., 2015; Vaughan et al., 2015; Zuo et al., 2015) (Figure 2B). Jain et al., (2015) have shown that terminally differentiated AT1 cells are able to regenerate AT2 cells during alveolar regrowth following partial pneumonectomy. While Vaughan et al., (2015) and Zuo et al., (2015) have described rare $\mathrm{Scgb1a} 1^{\text {neg }} \mathrm{SPC} C^{\text {neg }} \mathrm{p} 63^{\text {pos }} \mathrm{Krt} 5^{\text {pos }}$ peribronchiolar progenitor cells that are recruited to repair the alveolar epithelium following H1N1 influenza virus infection (Kumar et al., 2011; Vaughan et al., 2015; Zuo et al., 2015).

These latter progenitor cells, termed lineage negative epithelial cells (LNEP) by Vaughan et al., (2015), and distal airway stem cells (DASC) by Zuo et al., (2015) migrate from the distal airways migrate to the inflamed interstitial space of the injured lung where they proliferate and form pods resembling nascent alveoli. Pods formed by DASC eventually express AT2 and AT1 differentiation markers, and deletion of DASC prior to H1N1 infection results in failure of alveolar repair (Zuo et al., 2015). On the other hand, pods formed by LNEP do not mature and express AT2 and AT1 differentiation markers unless the Notch signalling pathway is suppressed (Vaughan et al., 2015). However, both ex vivo expanded DASC and freshly isolated LNEP are able to engraft and express alveolar and club cell differentiation markers following instillation into the lung following H1N1 infection. Although the patterns of alveolar regeneration attributed to DASC and LNEP differ following H1N1 viral infection, both studies show that they are essential for regeneration AT2 and AT1 epithelial cells following severe injury. Whether the differences in the regenerative properties of DASC and LNEP reflect differences in severity of injury, differences in experimental design, or co-fractionation of heterogeneous progenitors with an overlapping signature profile is yet to be determined.

\section{Adult lung stem and progenitor cell regulation}

Intrinsic stem cell potential: A number of recent reviews have summarised the evidence showing that adult lung epithelial stem and progenitor cells are regulated by the same highly conserved gene networks, signalling pathways, transcription factors, cytokines and epithelialmesenchymal cell interactions that play a critical role in branching morphogenesis and cell lineage specification during lung development (Akram et al., 2016; Herriges and Morrisey, 2014; Hogan et al., 2014; Shi et al., 2009; Warburton et al., 2010; Whitsett et al., 2011). This is 
consistent with the hypothesis adult lung regeneration and repair recapitulates ontogeny; and also with the observed dysregulation of these developmental pathways in disease pathogenesis (Boucherat et al., 2016). A brief overview is provided in Table 1.

Ongoing analysis continues to expand the list of critical genes and signalling pathways that regulate lung epithelial stem cells. Deletion of the histone methyltransferase, Ezh2, induces basal cell proliferation and reduces secretory epithelial cell differentiation during lung development (Galvis et al., 2015; Snitow et al., 2015). Repression of the Hippo/Yap signalling pathway enhances airway epithelial proliferation and inhibits sacculation in the fetal lung while causing airway hyperplasia in the adult lung (Lange et al., 2015). Differential expression of c-myb and Notch signalling via the Notch2 intracellular domain directs the differentiation of tracheal basal cells towards a ciliated or secretory cell lineage respectively (Pan et al., 2014; Pardo-Saganta et al., 2015).

Role of the niche microenvironment: The intrinsic regenerative capacity of stem cells is determined by their dynamic bidirectional communication and interaction with their niche microenvironment (Voog and Jones, 2010).

Highly conserved signalling pathways and paracrine factors elaborated by mesenchymal cells within the niche (e.g. BMP4, FGF-10, HGF, Shh, Wnt/ $\beta$-catenin, TGF- $\beta$ ) also play critical roles in regulating lung epithelial stem/progenitor cells during lung development, in adult lung homeostasis, and in lung regeneration and repair (Shi et al., 2009; Warburton et al., 2010) (Table 1). For example, FGF-10 maintains distal lung epithelial progenitors and prevents their differentiation into proximal airway epithelial cells during development, and initiates distal bronchiolar epithelial repair by variant club cells in the adult lung (Volckaert and De Langhe, 2014). The sonic hedgehog (SHH) pathway regulates lung morphogenesis during development, and maintains the balance between proliferation and quiescence of lung epithelial stem cells in the adult lung (Peng et al., 2015). And, BMP4 which regulates proximal-distal patterning in embryonic tracheal epithelium, acts as a brake on basal cell proliferation during lung homeostasis (Tadokoro et al., 2016).

The stem cell niche in the lung is a highly complex, changeable and malleable microenvironment (Schiller et al., 2015). Autocrine and paracrine factors elaborated by mesenchymal stromal cells and endothelial cells regulate lung epithelial cell proliferation and differentiation (McQualter and Bertoncello, 2012; Shi et al., 2009). Conversely, epithelial cell derived factors regulate mesenchymal and endothelial cell proliferation and 
differentiation. Cytokines, chemokines and inflammatory mediators elaborated during injury orchestrate immune responses which directly and indirectly influence epithelial progenitors, extracellular matrix deposition and remodelling (Burgess and Weckmann, 2012; Whitsett and Alenghat, 2015). While the amplitude and periodicity of cyclic stretch (Waters et al., 2012) and circadian rhythms in lung inflammatory responses (Sundar et al., 2015) also affect stem cell fate choices. The remediation of injury will require precise understanding of temporal changes in stem cell microenvironments during disease progression, and in the different phases of the response to injury.

\section{Limitations of extrapolating mouse models to humans}

The mouse is the most common animal model used to analyse lung development, regeneration and repair. The evolutionary conservation of $99 \%$ of genes in the mouse and human genome has enabled the identification of critical gene networks, signalling pathways and factors that are dysregulated in human disease. But while the mouse and human lung share much in common, there are also significant disparities that compromise the ability of mouse models to accurately predict the organisation and regulation of adult human lung stem and progenitor cells and their response to injury.

There are significant differences in the anatomical structure and cellular composition of mouse and human airways (Hyde et al., 2009; Rock et al., 2010). In mice, cartilage rings are restricted to extrapulmonary airways, whereas human cartilaginous airways extend for several generations. In mice, terminal bronchioles end in bronchioalveolar ducts, but transition into respiratory bronchioles separated by alveolar outpocketings in humans. Mucin-secreting goblet cells are abundant in human airways, but rare in mice. Pseudostratified, basal cell containing epithelium extends to the terminal bronchioles in humans, but is restricted to the trachea in mice. Conversely, simple cuboidal epithelium devoid of basal cells lines the bronchiolar airways of mice, but is only found in the respiratory bronchioles in humans.

There is also an enormous difference in the average size and gas-exchanging capacity of the mouse and human lung: an approximately 5000fold difference in weight $(0.2 \mathrm{gm}$ vs. $1.1 \mathrm{Kg})$, a 200 -fold difference in alveolar number $\left(2.3 \times 10^{6}\right.$ vs. $\left.480 \times 10^{6}\right)$; and a 15,000 -fold difference in 
alveolar surface area $\left(85 \mathrm{~cm}^{2}\right.$ vs. $130 \mathrm{~m}^{2}$ ) (Knust et al., 2009; Weibel, 2009). Consequently, the distribution and organisation of lung stem and progenitor cells will differ in the mouse and human lung. The very much longer telomeres of murine cells will also endow them with a replicative capacity unmatched by their human counterparts (Calado and Dumitriu, 2013).

Other traits of inbred mouse strains that compromise their ability to accurately model human lung regeneration and repair include genetically determined differences in extracellular matrix composition and lung tissue mechanics (Antunes et al., 2009; Wang et al., 2015), immune surveillance and inflammatory responses (Mestas and Hughes, 2004), and susceptibility to lung injury and fibrosis (Johnston et al., 1998; Walkin et al., 2013). Differences in resilience to lung injury and inflammatory challenge in mice also explains why genomic responses to acute inflammatory disease in human are poorly reproduced in mouse models (Seok et al., 2013). Moreover, experiments in mice are conducted in young healthy animals in controlled, often specific pathogen free, environments that do not replicate the human condition. Ultimately the specific properties of human lung stem and progenitor cells need to be worked out in translational human experiments.

\section{Human lung stem and progenitor cells}

Early studies describing the properties of presumptive human lung epithelial stem and progenitor cells using various in vivo and in vitro approaches have been reviewed previously (Bertoncello and McQualter, 2010; McQualter et al., 2014), so this mini-review will focus on more recent work in this area.

In comparison to mice, the characterisation of stem and progenitor cell targets in the human lung remains a work in progress. The limited availability of normal human lung tissue, and ethical and practical constraints limiting the ability of researchers to reproducibly harvest specific well-defined regions of the human airway tree are significant impediments. Consequently, researchers have had to source normal tissue from lung tumor resections (Butler et al., 2016; Oeztuerk-Winder et al., 2012; Rock et al., 2009; Ruiz et al., 2014); tracheobronchial biopsies (Butler et al., 2016); discarded airways from transplanted lungs (Hegab et al., 2012); or, lungs deemed unsuitable for transplant. Alternatively, 
researchers have procured early passage primary explanted lung epithelial cells from commercial sources propagated in proprietary media (Fessart et al., 2013; Wu et al., 2011). I am aware of only one study (Ghosh et al., 2013) that documented the use of cadaveric lung tissue sourced from relatively young accident victims without respiratory disease and normal respiratory parameters. The unique clinical history of individual patients also introduces potential sources of variability likely to affect biomarker signature profile and assay readouts that are not encountered in mouse models. These variables include the impact of prior therapies, unrelated health problems, opportunistic infections, trauma and ageing. To complicate matters further, most if not all of these studies, have used different protocols to dissociate cells; different biomarkers and gating strategies to analyse and isolate candidate stem and progenitor cells; and differently formulated cytokine supplemented media, culture conditions and assays to measure their regenerative potential. In some cases, primary explanted cells were also passaged in liquid culture prior to FACS analysis and sorting.

Most of the candidate lung progenitor cells analysed in these studies express biomarkers and potentialities associated with basal cells. Rock et al. (2009) have characterised a NGFR ${ }^{\text {pos }} \alpha 6^{\text {pos }}$ cell type that gives rise to tracheospheres containing peripheral Krt14 ${ }^{\text {pos }}$ p63 ${ }^{\text {pos }}$ basal cells and luminal Krt8 ${ }^{\text {pos }}$ non-ciliated and ciliated cells. Hegab et al. (2012) have characterised a NGFR ${ }^{\text {pos }} \mathrm{CD} 166^{\text {pos }} \mathrm{CD} 44^{\text {pos }}$ tracheal cell type that generates $\mathrm{Krt}^{\mathrm{pos}} \mathrm{Krt5} 5^{\mathrm{pos}}$ basal cells and serous and mucous secretory cells. Ghosh et al. (2013) characterised a subset of Krt5 ${ }^{\text {pos }} \mathrm{Krt1} 4^{\text {pos }}$ tracheobronchial cells isolated on the basis of their differential expression of tissue factor (TF) and CD151, showing that the most clonogenic sub-population

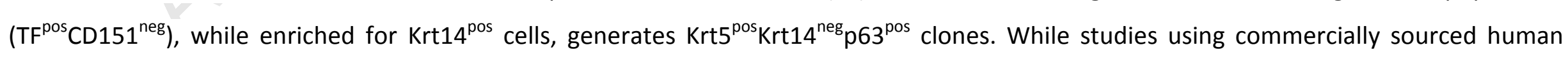
bronchial epithelial cells identified muc5 ${ }^{\text {pos }}$ mucous cells, lysozyme ${ }^{\text {pos }}$ lactoferrin ${ }^{\text {pos }}$ serous cells (Wu et al., 2011), and p63 ${ }^{\text {pos }}$ Muc5B ${ }^{\text {pos }}$ cells (Fessart et al., 2013) in spheroids growing in 3-D cultures. Using another approach, Butler et al. (2016) have recently devised a culture system for ex vivo expansion of basal cells from patient biopsies. These cultures are karyotypically normal, and retain their Krt5 ${ }^{\text {pos }} N G F R^{\text {pos }} \alpha 6^{\text {pos }} \operatorname{Trop}^{\text {pos }}$ signature profile and ability to generate tracheospheres comprising functional ciliated cells for many passages.

These studies suggest that basal cells are the dominant stem cell type responsible for the maintenance and repair of the human airways. Statistical modelling of the clonal pattern of accumulated mutations observed in resected human lung tissue shows that the upper airways are 
maintained by stochastic division of multipotent cells (Teixeira et al., 2013). However, the precise relationship, potentiality and organisation of the basal cell types with overlapping signature profiles characterised in each of these studies remains to be determined.

\section{Future directions}

Experimentation in mouse models has shown that lung regeneration and repair recapitulates ontogeny, utilising the same critical genes, signalling pathways and factors that build the lung during development. The dysregulation of many of these genes, signalling pathways and factors in chronic human lung diseases shows that mechanisms specifying lung stem cell fate and regulating lung regeneration and repair are evolutionarily conserved. However, while mouse models provide a sound rationale for translational studies, their failure to exactly recapitulate human lung diseases and human lung regeneration and repair (Williams and Roman, 2016) remains a major impediment to the development of effective clinical stem cell directed therapies.

$$
\text { for better b }
$$

There is a pressing need for better biomarkers to identify and characterise human lung stem and progenitor cells and monitor the status of

these compartments in the healthy and diseased lung. The recent analysis of the clonal dynamics of human basal stem cells by exploiting mtDNA mutations (Teixeira et al., 2013) provides a road-map for future studies of this kind. Standardised assays for the analysis of lung stem cell proliferation and differentiation would also be helpful in reconciling data obtained from differ studies and experimental designs.

Practical and ethical limitations in acquiring well annotated samples of normal lung tissue for delineating stem and progenitor cell hierarchies in the human lung will not be easily resolved. Induced pluripotent stem cells generated from normal and diseased human lung tissue are likely to provide a platform for the optimisation of clonogenic assays needed to analyse the organisation of human lung epithelial stem cells, and the microenvironmental cues important in maintaining, protecting and harnessing their regenerative potential (Hawkins and Kotton, 2015).

\section{Acknowledgements}


The reference limit has precluded the citation of many relevant papers in this mini-review. My apologies for their omission.

\section{Literature cited}

Adamson IY, Bowden DH. 1974. The type 2 cell as progenitor of alveolar epithelial regeneration. A cytodynamic study in mice after exposure to oxygen. Lab Invest 30(1):35-42.

Akram KM, Patel N, Spiteri MA, Forsyth NR. 2016. Lung Regeneration: Endogenous and Exogenous Stem Cell Mediated Therapeutic Approaches. Int J Mol Sci 17(1).

Antunes MA, Abreu SC, Damaceno-Rodrigues NR, Parra ER, Capelozzi VL, Pinart M, Romero PV, Silva PM, Martins MA, Rocco PR. 2009. Different strains of mice present distinct lung tissue mechanics and extracellular matrix composition in a model of chronic allergic asthma. Respir Physiol Neurobiol 165(2-3):202-207.

Barkauskas CE, Cronce MJ, Rackley CR, Bowie EJ, Keene DR, Stripp BR, Randell SH, Noble PW, Hogan BL. 2013. Type 2 alveolar cells are stem cells in adult lung. J Clin Invest 123(7):3025-3036.

Bertoncello I, McQualter JL. 2010. Endogenous lung stem cells: what is their potential for use in regenerative medicine? Expert review of respiratory medicine 4(3):349-362.

Bertoncello I, McQualter JL. 2013. Lung stem cells: do they exist? Respirology 18(4):587-595.

Borthwick DW, Shahbazian M, Krantz QT, Dorin JR, Randell SH. 2001. Evidence for stem-cell niches in the tracheal epithelium. Am J Respir Cell Mol Biol 24(6):662-670.

Boucherat O, Morissette MC, Provencher S, Bonnet S, Maltais F. 2016. Bridging Lung Development with Chronic Obstructive Pulmonary Disease. Relevance of Developmental Pathways in Chronic Obstructive Pulmonary Disease Pathogenesis. Am J Respir Crit Care Med 193(4):362-375. 
Bowden DH. 1983. Cell turnover in the lung. Am Rev Respir Dis 128(2 Pt 2):S46-48.

Branchfield K, Nantie L, Verheyden JM, Sui P, Wienhold MD, Sun X. 2016. Pulmonary neuroendocrine cells function as airway sensors to control lung immune response. Science 351(6274):707-710.

Burgess JK, Weckmann M. 2012. Matrikines and the lungs. Pharmacol Ther 134(3):317-337.

Burri PH. 2006. Structural aspects of postnatal lung development - alveolar formation and growth. Biology of the neonate 89(4):313-322.

Butler CR, Hynds RE, Gowers KH, Lee DD, Brown JM, Crowley C, Teixeira VH, Smith CM, Urbani L, Hamilton NJ, Thakrar RM, Booth HL, Birchall MA, De Coppi P, Giangreco A, O'Callaghan C, Janes SM. 2016. Rapid Expansion of Human Epithelial Stem Cells Suitable for Airway Tissue Engineering. Am J Respir Crit Care Med.

Calado RT, Dumitriu B. 2013. Telomere dynamics in mice and humans. Semin Hematol 50(2):165-174.

Carraro G, Stripp BR. 2015. A new notch for lung stem cells. Cell Stem Cell 16(2):107-109.

Chapman HA, Li X, Alexander JP, Brumwell A, Lorizio W, Tan K, Sonnenberg A, Wei Y, Vu TH. 2011. Integrin alpha6beta4 identifies an adult distal lung epithelial population with regenerative potential in mice. J Clin Invest 121(7):2855-2862.

Chen H, Matsumoto K, Brockway BL, Rackley CR, Liang J, Lee JH, Jiang D, Noble PW, Randell SH, Kim CF, Stripp BR. 2012. Airway epithelial progenitors are region specific and show differential responses to bleomycin-induced lung injury. Stem Cells 30(9):1948-1960.

Cole BB, Smith RW, Jenkins KM, Graham BB, Reynolds PR, Reynolds SD. 2010. Tracheal Basal cells: a facultative progenitor cell pool. Am J Pathol 177(1):362-376.

Cutz E. 2015. Hyperplasia of pulmonary neuroendocrine cells in infancy and childhood. Semin Diagn Pathol 32(6):420-437.

Evans MJ, Cabral-Anderson L, Freeman G. 1978. Role of the Clara cell in renewal of the bronchiolar epithelium. Lab Invest 38(6):648-653. 
Evans MJ, Johnson LV, Stephens RJ, Freeman G. 1976. Renewal of the terminal bronchiolar epithelium in the rat following exposure to NO2 or O3. Lab Invest 35(3):246-257.

Fessart D, Begueret H, Delom F. 2013. 3D culture model to distinguish normal from malignant human bronchial epithelial cells. Eur Respir J 42(5):1345-1356.

Galvis LA, Holik AZ, Short KM, Pasquet J, Lun AT, Blewitt ME, Smyth IM, Ritchie ME, Asselin-Labat ML. 2015. Repression of Igf1 expression by Ezh2 prevents basal cell differentiation in the developing lung. Development 142(8):1458-1469.

Ghosh M, Ahmad S, Jian A, Li B, Smith RW, Helm KM, Seibold MA, Groshong SD, White CW, Reynolds SD. 2013. Human tracheobronchial basal cells. Normal versus remodeling/repairing phenotypes in vivo and in vitro. Am J Respir Cell Mol Biol 49(6):1127-1134.

Ghosh M, Brechbuhl HM, Smith RW, Li B, Hicks DA, Titchner T, Runkle CM, Reynolds SD. 2011. Context-dependent differentiation of multipotential keratin 14-expressing tracheal basal cells. Am J Respir Cell Mol Biol 45(2):403-410.

Giangreco A, Arwert EN, Rosewell IR, Snyder J, Watt FM, Stripp BR. 2009. Stem cells are dispensable for lung homeostasis but restore airways after injury. Proc Natl Acad Sci U S A 106(23):9286-9291.

Goss RJ. 1966. Hypertrophy versus hyperplasia. Science 153(744):1615-1620.

Hackett NA. 1979. Proliferation of lung and airway cells induced by nitrogen dioxide. J Toxicol Environ Health 5(5):917-928.

Hawkins F, Kotton DN. 2015. Embryonic and induced pluripotent stem cells for lung regeneration. Ann Am Thorac Soc 12 Suppl 1:S50-53.

Hegab AE, Betsuyaku T, Gomperts BN. 2015. Stem and progenitor cells of the trachea and proximal airways. In: Bertoncello I, editor. Stem Cells in the Lung. Switzerland: Humana Press. p 97-112.

Hegab AE, Ha VL, Darmawan DO, Gilbert JL, Ooi AT, Attiga YS, Bisht B, Nickerson DW, Gomperts BN. 2012. Isolation and in vitro characterization of Basal and submucosal gland duct stem/progenitor cells from human proximal airways. Stem Cells Transl Med 1(10):719-724. 
Hegab AE, Ha VL, Gilbert JL, Zhang KX, Malkoski SP, Chon AT, Darmawan DO, Bisht B, Ooi AT, Pellegrini M, Nickerson DW, Gomperts BN. 2011. Novel stem/progenitor cell population from murine tracheal submucosal gland ducts with multipotent regenerative potential. Stem Cells 29(8):1283-1293.

Herriges M, Morrisey EE. 2014. Lung development: orchestrating the generation and regeneration of a complex organ. Development 141(3):502-513.

Hogan BL, Barkauskas CE, Chapman HA, Epstein JA, Jain R, Hsia CC, Niklason L, Calle E, Le A, Randell SH, Rock J, Snitow M, Krummel M, Stripp BR, Vu T, White ES, Whitsett JA, Morrisey EE. 2014. Repair and regeneration of the respiratory system: complexity, plasticity, and mechanisms of lung stem cell function. Cell Stem Cell 15(2):123-138.

Hong KU, Reynolds SD, Giangreco A, Hurley CM, Stripp BR. 2001. Clara cell secretory protein-expressing cells of the airway neuroepithelial body microenvironment include a label-retaining subset and are critical for epithelial renewal after progenitor cell depletion. Am J Respir Cell Mol Biol 24(6):671-681.

Hong KU, Reynolds SD, Watkins S, Fuchs E, Stripp BR. 2004a. Basal cells are a multipotent progenitor capable of renewing the bronchial epithelium. Am J Pathol 164(2):577-588.

Hong KU, Reynolds SD, Watkins S, Fuchs E, Stripp BR. 2004b. In vivo differentiation potential of tracheal basal cells: evidence for multipotent and unipotent subpopulations. Am J Physiol Lung Cell Mol Physiol 286(4):L643-649.

Hyde DM, Hamid Q, Irvin CG. 2009. Anatomy, pathology, and physiology of the tracheobronchial tree: emphasis on the distal airways. J Allergy Clin Immunol 124(6 Suppl):S72-77.

Jain R, Barkauskas CE, Takeda N, Bowie EJ, Aghajanian H, Wang Q, Padmanabhan A, Manderfield L, Gupta M, Li D, Li L, Trivedi CM, Hogan BL, Epstein JA. 2015. Plasticity of Hopx(+) type I alveolar cells to regenerate type II cells in the lung. Nat Commun 6:6727. 
Johnston CJ, Stripp BR, Piedbeouf B, Wright TW, Mango GW, Reed CK, Finkelstein JN. 1998. Inflammatory and epithelial responses in mouse strains that differ in sensitivity to hyperoxic injury. Exp Lung Res 24(2):189-202.

Kim CF, Jackson EL, Woolfenden AE, Lawrence S, Babar I, Vogel S, Crowley D, Bronson RT, Jacks T. 2005. Identification of bronchioalveolar stem cells in normal lung and lung cancer. Cell 121(6):823-835.

Knust J, Ochs M, Gundersen HJ, Nyengaard JR. 2009. Stereological estimates of alveolar number and size and capillary length and surface area in mice lungs. Anat Rec (Hoboken) 292(1):113-122.

Kotton DN, Morrisey EE. 2014. Lung regeneration: mechanisms, applications and emerging stem cell populations. Nat Med 20(8):822-832.

Kumar PA, Hu Y, Yamamoto Y, Hoe NB, Wei TS, Mu D, Sun Y, Joo LS, Dagher R, Zielonka EM, Wang de Y, Lim B, Chow VT, Crum CP, Xian W, McKeon F. 2011. Distal airway stem cells yield alveoli in vitro and during lung regeneration following H1N1 influenza infection. Cell 147(3):525-538.

Kuo CS, Krasnow MA. 2015. Formation of a Neurosensory Organ by Epithelial Cell Slithering. Cell 163(2):394-405.

Lange AW, Sridharan A, Xu Y, Stripp BR, Perl AK, Whitsett JA. 2015. Hippo/Yap signaling controls epithelial progenitor cell proliferation and differentiation in the embryonic and adult lung. J Mol Cell Biol 7(1):35-47.

McQualter JL, Anthony D, Bozinovski S, Prele CM, Laurent GJ. 2014. Harnessing the potential of lung stem cells for regenerative medicine. Int J Biochem Cell Biol 56:82-91.

McQualter JL, Bertoncello I. 2012. Concise review: Deconstructing the lung to reveal its regenerative potential. Stem Cells 30(5):811-816.

McQualter JL, Yuen K, Williams B, Bertoncello I. 2010. Evidence of an epithelial stem/progenitor cell hierarchy in the adult mouse lung. Proc Natl Acad Sci U S A 107(4):1414-1419.

Mestas J, Hughes CC. 2004. Of mice and not men: differences between mouse and human immunology. J Immunol 172(5):2731-2738. 
Morrisey EE, Hogan BL. 2010. Preparing for the first breath: genetic and cellular mechanisms in lung development. Dev Cell 18(1):8-23.

Nadkarni RR, Abed S, Draper JS. 2015. Organoids as a model system for studying human lung development and disease. Biochem Biophys Res Commun.

Nolen-Walston RD, Kim CF, Mazan MR, Ingenito EP, Gruntman AM, Tsai L, Boston R, Woolfenden AE, Jacks T, Hoffman AM. 2008. Cellular kinetics and modeling of bronchioalveolar stem cell response during lung regeneration. Am J Physiol Lung Cell Mol Physiol 294(6):L1158-1165.

Oeztuerk-Winder F, Guinot A, Ochalek A, Ventura JJ. 2012. Regulation of human lung alveolar multipotent cells by a novel p38alpha MAPK/miR17-92 axis. EMBO J 31(16):3431-3441.

Pan JH, Adair-Kirk TL, Patel AC, Huang T, Yozamp NS, Xu J, Reddy EP, Byers DE, Pierce RA, Holtzman MJ, Brody SL. 2014. Myb permits multilineage airway epithelial cell differentiation. Stem Cells 32(12):3245-3256.

Pardo-Saganta A, Law BM, Tata PR, Villoria J, Saez B, Mou H, Zhao R, Rajagopal J. 2015. Injury induces direct lineage segregation of functionally distinct airway basal stem/progenitor cell subpopulations. Cell Stem Cell 16(2):184-197.

Peake JL, Reynolds SD, Stripp BR, Stephens KE, Pinkerton KE. 2000. Alteration of pulmonary neuroendocrine cells during epithelial repair of naphthalene-induced airway injury. Am J Pathol 156(1):279-286.

Peng T, Frank DB, Kadzik RS, Morley MP, Rathi KS, Wang T, Zhou S, Cheng L, Lu MM, Morrisey EE. 2015. Hedgehog actively maintains adult lung quiescence and regulates repair and regeneration. Nature 526(7574):578-582.

Rawlins EL, Hogan BL. 2008. Ciliated epithelial cell lifespan in the mouse trachea and lung. Am J Physiol Lung Cell Mol Physiol 295(1):L231-234.

Rawlins EL, Okubo T, Xue Y, Brass DM, Auten RL, Hasegawa H, Wang F, Hogan BL. 2009. The role of Scgb1a1+ Clara cells in the long-term maintenance and repair of lung airway, but not alveolar, epithelium. Cell Stem Cell 4(6):525-534. 
Reynolds SD, Giangreco A, Power JH, Stripp BR. 2000. Neuroepithelial bodies of pulmonary airways serve as a reservoir of progenitor cells capable of epithelial regeneration. Am J Pathol 156(1):269-278.

Rock JR, Onaitis MW, Rawlins EL, Lu Y, Clark CP, Xue Y, Randell SH, Hogan BL. 2009. Basal cells as stem cells of the mouse trachea and human airway epithelium. Proc Natl Acad Sci U S A 106(31):12771-12775.

Rock JR, Randell SH, Hogan BL. 2010. Airway basal stem cells: a perspective on their roles in epithelial homeostasis and remodeling. Dis Model Mech 3(9-10):545-556.

Ruiz EJ, Oeztuerk-Winder F, Ventura JJ. 2014. A paracrine network regulates the cross-talk between human lung stem cells and the stroma. Nat Commun 5:3175.

Schiller HB, Fernandez IE, Burgstaller G, Schaab C, Scheltema RA, Schwarzmayr T, Strom TM, Eickelberg O, Mann M. 2015. Time- and compartment-resolved proteome profiling of the extracellular niche in lung injury and repair. Molecular systems biology 11(7):819.

Seok J, Warren HS, Cuenca AG, Mindrinos MN, Baker HV, Xu W, Richards DR, McDonald-Smith GP, Gao H, Hennessy L, Finnerty CC, Lopez CM, Honari S, Moore EE, Minei JP, Cuschieri J, Bankey PE, Johnson JL, Sperry J, Nathens AB, Billiar TR, West MA, Jeschke MG, Klein MB, Gamelli RL, Gibran NS, Brownstein BH, Miller-Graziano C, Calvano SE, Mason PH, Cobb JP, Rahme LG, Lowry SF, Maier RV, Moldawer LL, Herndon DN, Davis RW, Xiao W, Tompkins RG, Inflammation, Host Response to Injury LSCRP. 2013. Genomic responses in mouse models poorly mimic human inflammatory diseases. Proc Natl Acad Sci U S A 110(9):3507-3512.

Shi W, Xu J, Warburton D. 2009. Development, repair and fibrosis: what is common and why it matters. Respirology 14(5):656-665.

Shorter RG, Titus JL, Divertie MB. 1964. Cell Turnover in the Respiratory Tract. Diseases of the chest 46:138-142.

Snitow ME, Li S, Morley MP, Rathi K, Lu MM, Kadzik RS, Stewart KM, Morrisey EE. 2015. Ezh2 represses the basal cell lineage during lung endoderm development. Development 142(1):108-117. 
Song H, Yao E, Lin C, Gacayan R, Chen MH, Chuang PT. 2012. Functional characterization of pulmonary neuroendocrine cells in lung development, injury, and tumorigenesis. Proc Natl Acad Sci U S A 109(43):17531-17536.

Sundar IK, Yao H, Sellix MT, Rahman I. 2015. Circadian molecular clock in lung pathophysiology. Am J Physiol Lung Cell Mol Physiol 309(10):L1056-1075.

Tadokoro T, Gao X, Hong CC, Hotten D, Hogan BL. 2016. BMP signaling and cellular dynamics during regeneration of airway epithelium from basal progenitors. Development.

Tata PR, Mou H, Pardo-Saganta A, Zhao R, Prabhu M, Law BM, Vinarsky V, Cho JL, Breton S, Sahay A, Medoff BD, Rajagopal J. 2013. Dedifferentiation of committed epithelial cells into stem cells in vivo. Nature 503(7475):218-223.

Teixeira VH, Nadarajan P, Graham TA, Pipinikas CP, Brown JM, Falzon M, Nye E, Poulsom R, Lawrence D, Wright NA, McDonald S, Giangreco A, Simons BD, Janes SM. 2013. Stochastic homeostasis in human airway epithelium is achieved by neutral competition of basal cell progenitors. Elife 2:e00966.

Tropea KA, Leder E, Aslam M, Lau AN, Raiser DM, Lee JH, Balasubramaniam V, Fredenburgh LE, Alex Mitsialis S, Kourembanas S, Kim CF. 2012. Bronchioalveolar stem cells increase after mesenchymal stromal cell treatment in a mouse model of bronchopulmonary dysplasia. Am J Physiol Lung Cell Mol Physiol 302(9):L829-837.

Vaughan AE, Brumwell AN, Xi Y, Gotts JE, Brownfield DG, Treutlein B, Tan K, Tan V, Liu FC, Looney MR, Matthay MA, Rock JR, Chapman HA. 2015. Lineage-negative progenitors mobilize to regenerate lung epithelium after major injury. Nature 517(7536):621-625.

Volckaert T, De Langhe S. 2014. Lung epithelial stem cells and their niches: Fgf10 takes center stage. Fibrogenesis Tissue Repair 7:8.

Voog J, Jones DL. 2010. Stem cells and the niche: a dynamic duo. Cell Stem Cell 6(2):103-115. 
Walkin L, Herrick SE, Summers A, Brenchley PE, Hoff CM, Korstanje R, Margetts PJ. 2013. The role of mouse strain differences in the susceptibility to fibrosis: a systematic review. Fibrogenesis Tissue Repair 6(1):18.

Wang L, Liu H, Jiao Y, Wang E, Clark SH, Postlethwaite AE, Gu W, Chen H. 2015. Differences between Mice and Humans in Regulation and the Molecular Network of Collagen, Type III, Alpha-1 at the Gene Expression Level: Obstacles that Translational Research Must Overcome. Int J Mol Sci 16(7):15031-15056.

Warburton D, El-Hashash A, Carraro G, Tiozzo C, Sala F, Rogers O, De Langhe S, Kemp PJ, Riccardi D, Torday J, Bellusci S, Shi W, Lubkin SR, Jesudason E. 2010. Lung organogenesis. Curr Top Dev Biol 90:73-158.

Waters CM, Roan E, Navajas D. 2012. Mechanobiology in lung epithelial cells: measurements, perturbations, and responses. Compr Physiol 2(1):1-29.

Watson JK, Rulands S, Wilkinson AC, Wuidart A, Ousset M, Van Keymeulen A, Gottgens B, Blanpain C, Simons BD, Rawlins EL. 2015. Clonal Dynamics Reveal Two Distinct Populations of Basal Cells in Slow-Turnover Airway Epithelium. Cell Rep 12(1):90-101.

Weibel ER. 2009. What makes a good lung? Swiss Med Wkly 139(27-28):375-386.

White ES. 2015. Lung extracellular matrix and fibroblast function. Ann Am Thorac Soc 12 Suppl 1:S30-33.

Whitsett JA, Alenghat T. 2015. Respiratory epithelial cells orchestrate pulmonary innate immunity. Nat Immunol 16(1):27-35.

Whitsett JA, Haitchi HM, Maeda Y. 2011. Intersections between pulmonary development and disease. Am J Respir Crit Care Med 184(4):401406.

Williams K, Roman J. 2016. Studying human respiratory disease in animals - role of induced and naturally occurring models. J Pathol 238(2):220232. 
Wu X, Peters-Hall JR, Bose S, Pena MT, Rose MC. 2011. Human bronchial epithelial cells differentiate to 3D glandular acini on basement membrane matrix. Am J Respir Cell Mol Biol 44(6):914-921.

Zacharek SJ, Fillmore CM, Lau AN, Gludish DW, Chou A, Ho JW, Zamponi R, Gazit R, Bock C, Jager N, Smith ZD, Kim TM, Saunders AH, Wong J, Lee JH, Roach RR, Rossi DJ, Meissner A, Gimelbrant AA, Park PJ, Kim CF. 2011. Lung stem cell self-renewal relies on BMI1-dependent control of expression at imprinted loci. Cell Stem Cell 9(3):272-281.

Zuo W, Zhang T, Wu DZ, Guan SP, Liew AA, Yamamoto Y, Wang X, Lim SJ, Vincent M, Lessard M, Crum CP, Xian W, McKeon F. 2015. p63(+)Krt5(+) distal airway stem cells are essential for lung regeneration. Nature 517(7536):616-620.

\section{FIGURE LEGENDS}

Figure 1: A schematic representation of the spatial location and distribution of endogenous epithelial stem and progenitor cells along the proximal-distal axis of the airways and alveolar bed of the adult mouse.

Figure 2: Severe injury reveals the heterogeneity and plasticity of regenerative cells in the adult mouse lung. (A) Following $\mathrm{SO}_{2}$ ablation of luminal tracheobronchiolar epithelial cells, basal stem cells give rise to two discrete basal cell subpopulations: N2ICD pos precursors of luminal secretory cells; and c-myb ${ }^{\text {pos }}$ precursors of ciliated cells. There is also evidence that luminal secretory cells are able to de-differentiate to regenerate ablated basal stem cells following severe injury. (B) AT2 cells are the stem cells of the alveolar bed, giving rise to gas-exchanging AT1 cells. Following 
severe injury, AT1 cells have been shown to de-differentiate and replenish the AT2 stem cell compartment. During recovery from H1N1 viral infection, para-basal stem/progenitor cells termed DASC or LNEP have been shown to migrate into the alveolar bed and regenerate alveolar epithelial cell lineages independently of AT2 cells.

TABLE 1: The role of key signalling pathways, genes and factors associated with lung epithelial cell proliferation and differentiation during lung development, regeneration and repair*

\begin{tabular}{|c|c|c|c|c|}
\hline Gene & Molecular Function & Lung development & $\begin{array}{l}\text { Adult lung regeneration and } \\
\text { repair }\end{array}$ & Pathophysiology \\
\hline Wnt & Signal & $\begin{array}{l}\text { Regulates early lung } \\
\text { endodermal specification }\end{array}$ & $\begin{array}{l}\text { Expansion of the BASC } \\
\text { compartment following injury }\end{array}$ & $\begin{array}{l}\text { Chronic activation is associated } \\
\text { with increased fibrosis }\end{array}$ \\
\hline Notch & Signaling pathway & $\begin{array}{l}\text { Differentiation of secretory } \\
\text { epithelium from proximal } \\
\text { endoderm }\end{array}$ & $\begin{array}{l}\text { Differentiation of basal cells } \\
\text { into secretory cells after severe } \\
\text { injury }\end{array}$ & $\begin{array}{l}\text { Excess notch signalling } \\
\text { promotes mucous metaplasia; } \\
\text { loss of notch signalling induces } \\
\text { ciliated cell differentiation }\end{array}$ \\
\hline $\begin{array}{l}\text { TTF-1 } \\
(\mathrm{Nkx} 2.1)\end{array}$ & Transcription factor & $\begin{array}{l}\text { Required for formation of lung } \\
\text { parenchyma and differentiation } \\
\text { of lung epithelial lineages }\end{array}$ & $\begin{array}{l}\text { Required for normal } \\
\text { differentiation of airway and } \\
\text { alveolar epithelial cells }\end{array}$ & $\begin{array}{l}\text { Mutations cause lung diseases } \\
\text { of varying severity (e.g. alveolar } \\
\text { dysgenesis, interstitial lung } \\
\text { disease) }\end{array}$ \\
\hline Sox-2 & Transcription factor & $\begin{array}{l}\text { Normal patterning of proximal } \\
\text { airway epithelial lineages }\end{array}$ & $\begin{array}{l}\text { Activated after injury to induce } \\
\text { differentiation of ciliated, club, } \\
\text { basal and goblet cells }\end{array}$ & $\begin{array}{l}\text { Deletion produces airways } \\
\text { devoid of normal epithelial cell } \\
\text { types }\end{array}$ \\
\hline Gata-6 & Transcription factor & $\begin{array}{l}\text { Regulates lung epithelial gene } \\
\text { transcription during }\end{array}$ & $\begin{array}{l}\text { Maintains distal airway } \\
\text { homeostasis, regulating }\end{array}$ & $\begin{array}{l}\text { Suppression of Gata- } 6 \text { is } \\
\text { associated with lung }\end{array}$ \\
\hline
\end{tabular}


development

SPDE

Transcription factor

Myb

Transcription factor

HDAC1/2 Histone deacetylases: catalyse removal of acetyl functional groups

$\mathrm{SHH}$ Growth factor

Growth factor

HGF
Differentiation of goblet cells from basal and non-ciliated columnar epithelial cells

Required for multiciliated cell differentiation

Regulation of Sox 2 expression required for development of proximal airways

Expressed in epithelium during lung development regulating interaction between epithelial and mesenchymal cells during branching morphogenesis

Branching morphogenesis; saccular lung development; tracheal basal cell maintenance and differentiation

Required for alveologenesis balance between BASC renewal and differentiation via Wnt

signalling pathway

Required for goblet cell differentiation in normal submucosal glands; and following allergen exposure

Required for differentiation of ciliated and secretory cells in proximal airways

Regulates lung epithelial regeneration by reactivation of cell cycle progression

Unclear

\section{fibrosis; associated with bronchopulmonary dysplasia}

Promotes re-epithelialisation of injured airways by stimulating

lung epithelial stem cell proliferation

Promotes lung repair following injury
Upregulation exacerbates lung

Deletion blocks goblet cell differentiation in airways and sub-mucosal glands

$\mathrm{Myb}^{\text {pos }}$ cells are elevated in chronic airway disease; Inactivation leads to failure of proper airway ciliation

Deletion of HDAC1/2 results in defective airway repair;

inhibition causes emphysema

Reduced FgF10 expression is associated with bronchopulmonary dysplasia

Mice lacking HGF receptor (Met) have impaired airspace 
*Compiled from (Akram et al., 2016; Boucherat et al., 2016; Herriges and Morrisey, 2014; Volckaert and De Langhe, 2014; Whitsett et al., 2011) 


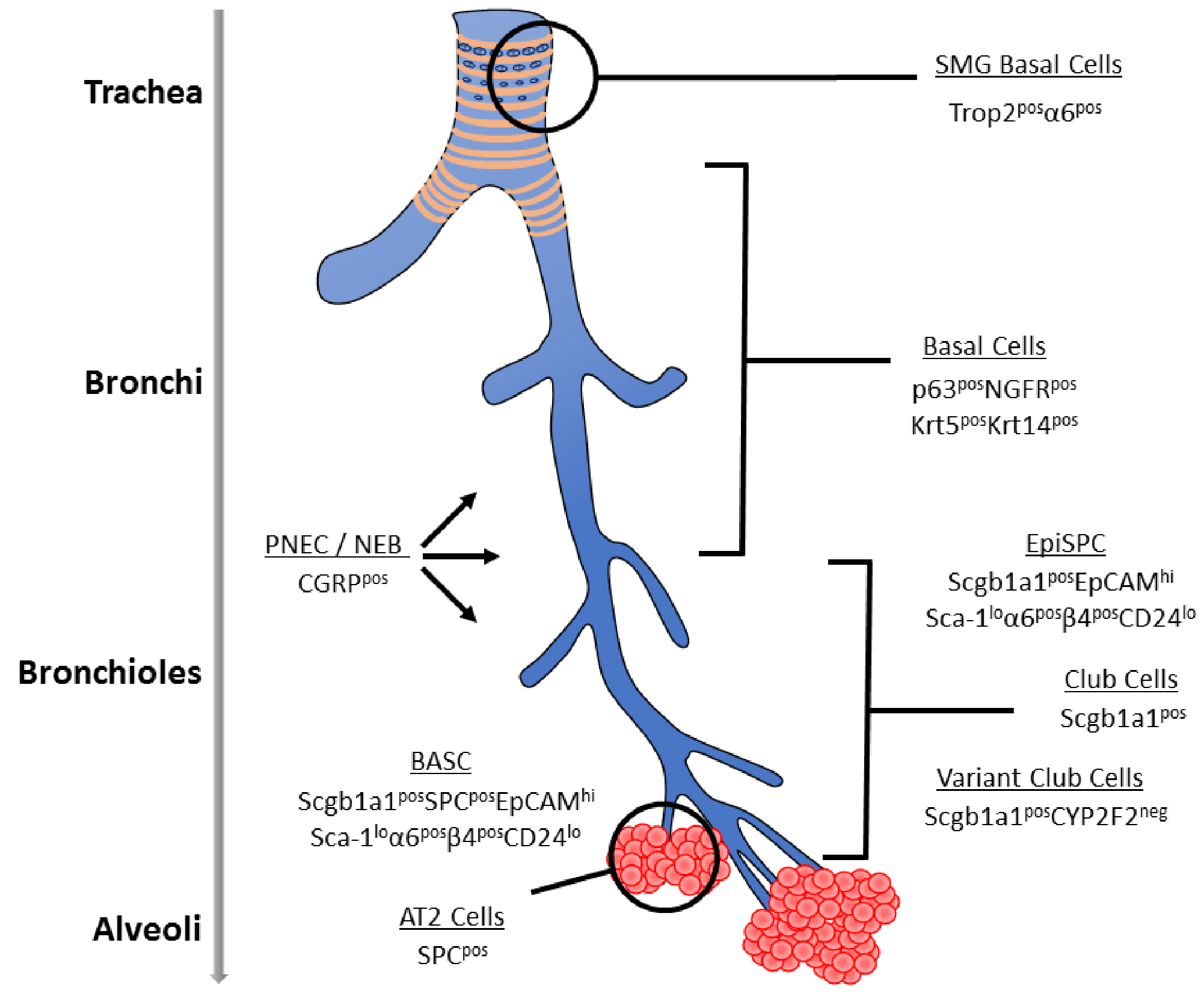


Figure 1 .

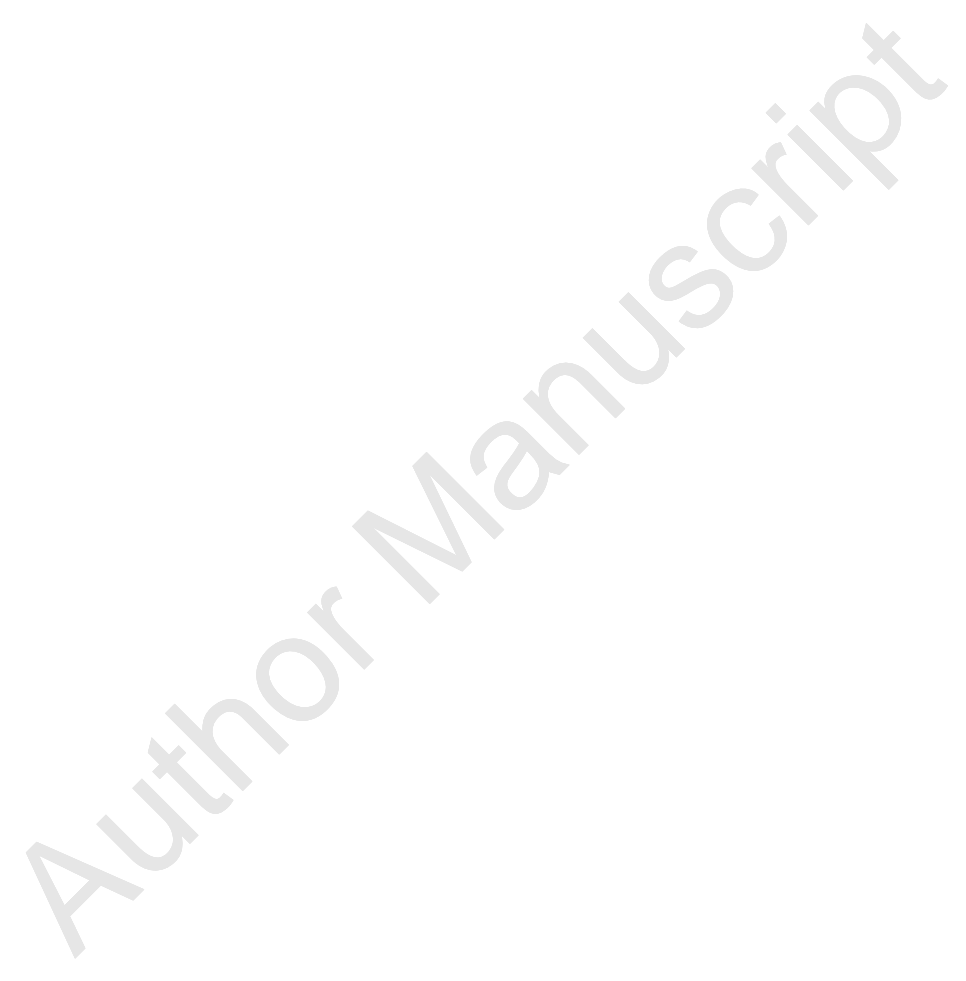



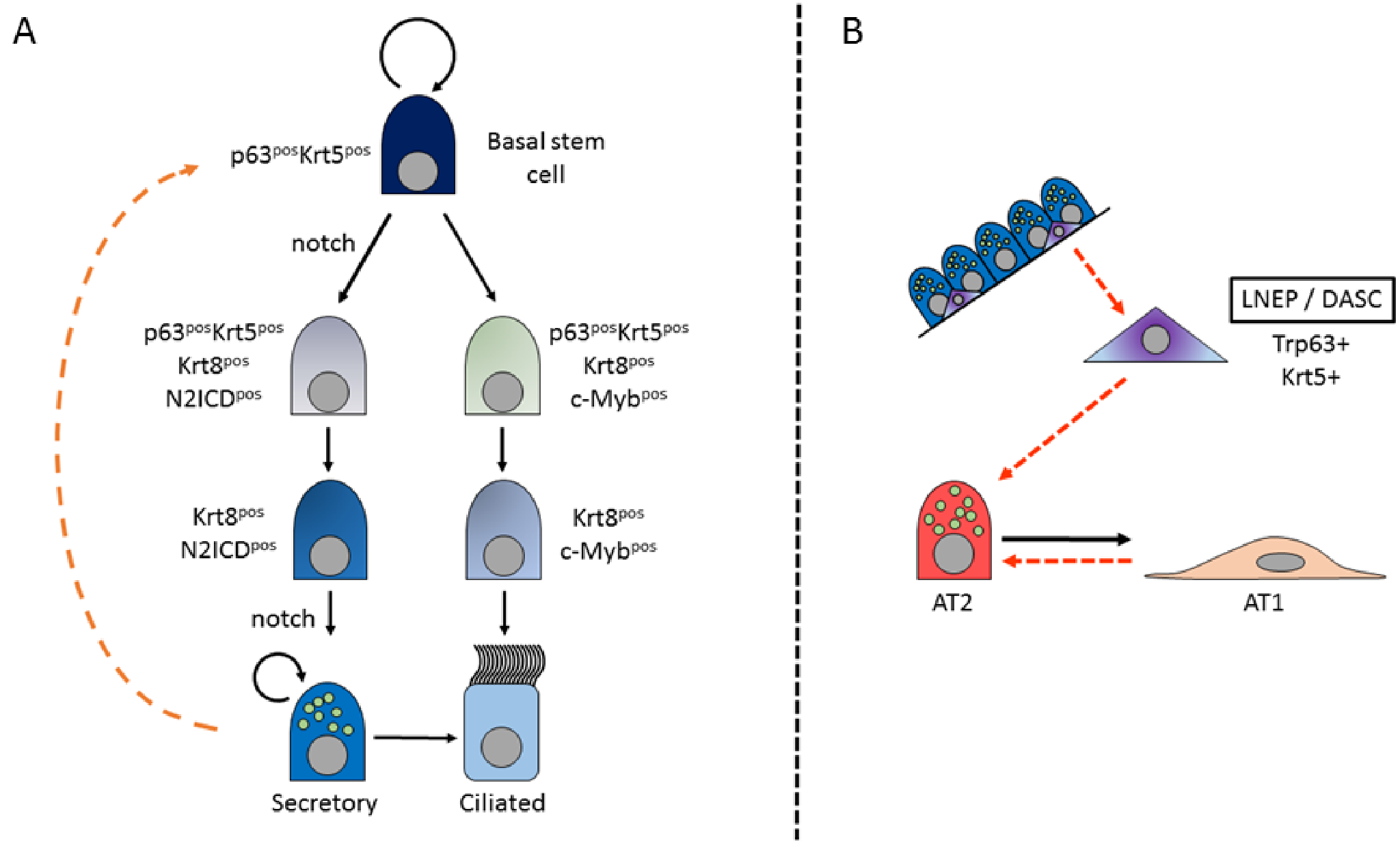
Figure 2.

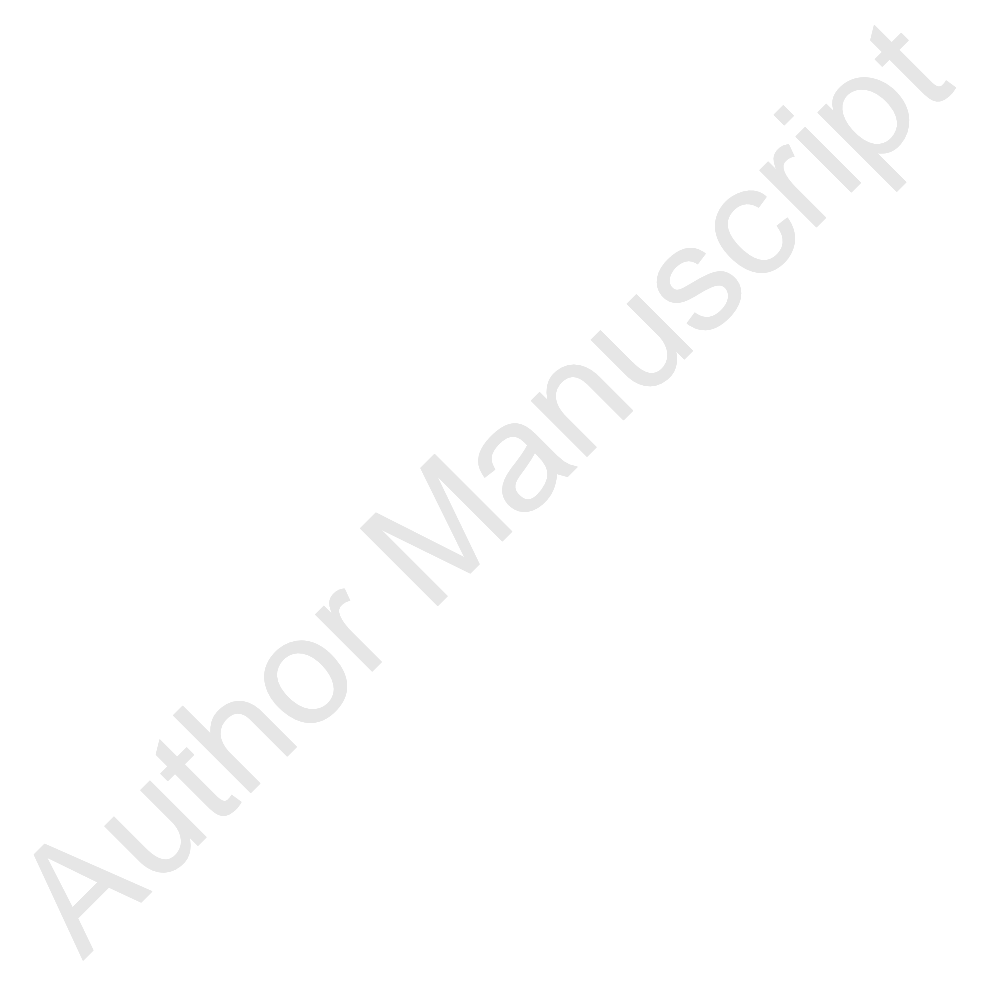




\section{University Library}

\section{- M M I E E R VA A gateway to Melbourne's research publications}

Minerva Access is the Institutional Repository of The University of Melbourne

Author/s:

Bertoncello, I

Title:

Properties of Adult Lung Stem and Progenitor Cells

Date:

2016-12-01

Citation:

Bertoncello, I. (2016). Properties of Adult Lung Stem and Progenitor Cells. JOURNAL OF CELLULAR PHYSIOLOGY, 231 (12), pp.2582-2589. https://doi.org/10.1002/jcp.25404.

Persistent Link:

http://hdl.handle.net/11343/291192 